\title{
PENGARUH EXPERIENTIAL MARKETING TERHADAP MINAT BELI ULANG DAN WORD OF MOUTH DENGAN CUTOMER SATISFACTION SEBAGAI VARIABEL INTERVENING ( Study Kasus Legend Coffee Yogyakarta )
}

\author{
Suyetno \\ Alumni Fakultas Ekonomi Universitas Sarjanawiyata Tamansiswa Yogyakarta \\ Email: Syetnoooyetnooo@,gmail.com
}

\begin{abstract}
Intisari
Tujuan penelitian ini adalah untuk mengetahui Analisis Pengaruh Experiential Marketing terhadap Minat Beli Ulang dan Word Of Mouth dengan Customer Satisfaction sebagai variabel intervening (Study Kasus Legend Coffee Yogyakarta). Penelitian ini merupakan penelitian kuantitatif. Sampel dalam penelitian ini adalah konsumen yang berbelanja di Legend Coffee Yogyakarta dengan minimal sebanyak dua kali, Pengumpulan data dilakukan dengan menggunakan metode angket atau kuesioner. Teknik analisis data yang digunakan adalah teknik regresi yang didukung dengan uji $\mathrm{t}$ dan asumsi klasik, data yang telah didapatkan diolah menggunakan SPSS 21. Hasil dari penelitian ini menunjukan bahwa Experiential Marketing berpengaruh positif dan signifikan terhadap Customer Satisfaction, Eperiential Marketing berpengaruh positif dan signifikan terhadap Minat Beli Ulang dan Word Of Mouth, Customer Satisfaction berpengaruh positif dan signifikan terhadap Minat Beli Ulang dan Word Of Mouth.
\end{abstract}

Kata kunci: Experiential Marketing, Customer Satisfaction, Minat Beli Ulang, Word Of Mouth

\begin{abstract}
The purpose of this study was to study the Analysis of the Effect of Experiential Marketing on Repurchase Interest and Word of Mouth with Customer Satisfaction as an intervening variable (Case Study of Legend Coffee Yogyakarta). This research is a quantitative research. The sample in this study is consumers who shop at Legend Coffee Yogyakarta with a minimum of two times. Data collection was carried out using a questionnaire or questionnaire method. Data analysis technique used is a regression technique that is supported by the $t$ test and classical assumptions, the data obtained were processed using SPSS 21. The results of this study indicate that Experiential Marketing has a positive and significant effect on Customer Satisfaction, Eperiential Marketing has a positive and significant effect on Repurchase Interest and Word of Mouth, Customer Satisfaction has a positive and significant effect on Repurchase Interest and Word of Mouth.
\end{abstract}

Keywords: Experiential Marketing, Customer Satisfaction, Repurchase Interest, Word Of Mouth

\section{PENDAHULUAN}

Perkembangan sektor usaha industri makanan dan minuman di Indonesia semakin berkembang dengan pesat. Dalam 3 tahun terakhir industri makanan dan minuman mengalami pertumbuhan secara signifikan. Salah satu kafe yang diminati di Yogyakarta yaitu Legend Coffee. Legend Coffee terletak di Jalan Abu Bakar Ali 24, Kota Baru, Yogyakarta. Legend Coffee hadir dengan konsep one stop nongkrong yang berada diujung Jalan Abu Bakar ali Yogyakarta selain dapat menikmati berbagai varian kopi serta makanan yang nikmat. Legend Coffee juga merupakan cafe yang unik, karena selain buka 24 jam, Legend Coffee merupakan cafe yang pertama di Yogyakarta yang mengusung konsep cafe dengan permainan. Selain menawarkan coffee, latte, cokelat dan minuman yang lain, menu yang di tawarkan di Legend 
Coffee juga beragam yang terdiri dari masakan western dan juga hidangan lokal seperti roti bakar, pisang bakar, mendoan dan chickhen wings serta berbagai macam sandwich untuk hidangan western, untuk menu utama masakan Indonesia Legend Coffee menawarkan bermacam menu nasi goreng, penyetan dan sop. Selain menu di atas, konsumen juga bisa bersantai dan menikmati live music acaoustik setiap hari. Terdapat banyak persaingan usaha dalam bidang cafetaria, terutama coffee shop di Yogyakarta, Legend Coffee memiliki cara tersendiri untuk menjadi pilihan khusus bagi konsumennya yang merupakan penikmat kuliner, diantaranya yaitu memberikn kualitas pelayanan yang baik, sopan dan ramah bagi pengunjungnya memperlakukan konsumen atau pengunjung dengan baik.

Legend Coffee harus memperhatikan experiential marketing untuk menarik pelanggan datang. konsep marketing yang dapat digunakan yaitu mempengaruhi emosi konsumen yaitu melalui experiential marketing, experiential marketing yaitu suatu konsep pemasaran yang tidak hanya sekedar memberikan informasi dan peluang pada pelanggan untuk memperoleh pengalaman atas keuntungan yang didapat tetapi juga membangkitkan emosi dan perasaan yang berdampak terhadap pemasaran, khususnya penjualan Andreani (2007) dalam Barimbing \& Sari (2015).

Dengan terciptanya kepuasan pelanggan maka minat beli ulang pelanggan akan berlangsung terus menerus. Kecenderungan seseorang untuk memberikan perhatian apabila disertai dengan perasaan suka. Minat tersebut apabila sudah terbentuk pada diri seseorang maka cenderung menetap sepanjang obyek minat tersebut efektif baginya, sehingga apabila obyek minat tersebut tidak efektif lagi maka minatnya pun cenderung berubah.

Kepuasan pelanggan akan suatu produk dan jasa juga mempengaruhi pelanggan untuk merekomendasikan atau membicarakan produk dan jasa yang ada di Legend Coffee kepada orang lain. Word of mouth merupakan cara membuat pelanggan membicarakan, merekomendasikan, dan membantu penjualan perusahaan. Kunci utama word of mouth merupakan kekuatan untuk mempengaruhi sebuah kepuasan. Para pemimpin pada umumnya akan lebih didengar karena pemimpin dianggap memiliki pengetahuan dan pengalaman yang lebih. pemimpin merupakan aset penting bagi perusahaan, ketika perusahaan dapat memuaskan pelanggan maka akan sangat menentukan efektifitas word of mouth yang telah perusahaan lakukan

Kepuasan pelanggan dipenggaruhi oleh hubungan yang baik antara Legend Coffee dengan pelanggan. Hubungan tersebut akan menciptakan Minat Beli Ulang pelanggan akan produk atau menu yang ada di Legend Coffee. Pelanggan yang merasa puas akan produk atau jasa yang ada di Legend Coffee akan merekomendasikan kepada orang lain. Dengan begitu kepuasan pelanggan dapat ditentukan oleh presepsi pelanggan terhadap produk dan jasa yang ada di Legend Coffee.

\section{TINJAUAN PUSTAKA DAN PENGEMBANGAN HIPOTESIS}

Experiential marketing merupakan proses untuk mengidentifikasi dan memuaskan kebutuhan dan aspirasi pelanggan, menyatukannya melalui komunikasi dua arah yang membawa merek ke dalam kehidupan dan membawa nilai ke pelanggan yang dituju. Experiential Marketing berperan penting dalam menciptakan kepuasan pada pelanggan. penelitian yang dilakukan Ratih Kusuma Dewi, Srikandi Kumadji, dan M. Kholid Mawardi tahun (2015) dapat disimpulkan: Hasil analisis jalur menunjukkan bahwa variabel experiential marketing memiliki pengaruh positif dan signifikan terhadap variabel kepuasan pelanggan. Hasil ini diperkuat dengan hasil penelitian yang menunjukkan koefisien jalur $(\beta)$ sebesar 0,782 dengan probabilitas sebesar $0,000(\mathrm{p}<0,05)$ sehingga dinyatakan signifikan.

\section{H1: Experiential Marketing berpengaruh positif terhadap customer satisfaction}


Experience yaitu sebagai sebuah bagian subjektif dalam konstruksi atau transformasi dari individu, dalam penekanan pada emosi dan indra secara langsung selama perendaman dengan mengorbankan dimensi kognitif. Hasil penelitian menunjukkan bahwa Experiential Marketing memiliki pengaruh yang signifikan terhadap Pembelian Ulang. Hal ini sesuai dengan penelitian yang dilakukan apabila produk atau jasa tersebut mampu untuk menghadirkan pengalaman positif yang tak terlupakan (Memorable Experience) yang menyentuh sisi afeksi mereka, marketing secara positif dan signifikan (nilai probability 0.013) mempengaruhi secara langsung terhadap pembelian ulang.

\section{H2: Experiential Marketing berpengaruh positif terhadap pembelian ulang.}

Word Of mouth merupakan suatu komunikasi interpersonal tentang produk diantara pembeli dan orang-orang di sekitarnya (Kotler \& Keller, 2009). Variabel-variabel yang mempengaruhi terciptanya WOM diantaranya, variabel yang mempengaruhi WOM yaitu kepuasan pelanggan, kualitas produk dan variabel yang mempengaruhi WOM yaitu Experiential Marketing. Variabel-variabel tersebut bisa berpengaruh positif dan negatif terhadap WOM itu semua tergantung dari perusahaan. Jika perusahaan bisa menghasilkan variabel tersebut menjadi positif maka WOM yang di ciptakan akan berpengaruh positif juga terhdapat perusahaan begitupun sebaliknya. pengaruh Expereiential Marketing yang meliputi sense (rasa), feel (perasaan), Think (persepsi tentang apa yang di pikirkaan) Berpengaruh positif terhadap Word Of mouth. Hasil ini sesuai dengan penelitian sebelumnya yang dilakukan Mismiwati (2016) yang menyatakan bahwa Expereiential Marketing terhadap Word Of Mouth.

\section{H3: Experiential Marketing berpengaruh positif terhadap word of mouth}

Kepuasan pelanggan merupakan perasaan yang terjadi pada pelanggan setelah menyelesaikan pembelian dalam fase setelah akuisisi pelayanan. Jika pelanggan percaya bahwa kinerja sebuah pelayanan lebih baik daripada yang mereka harapkan, mereka yakin puas (Allameh et al., 2015). Selain itu, banyak penelitian telah mengidentifikasi kepuasan pelanggan sebagai penentu penting dari niat membeli kembali. Kepuasan pelanggan berpengaruh positif dan signifikan dalam meningkatkan niat beli ulang (Palma dan Andjarwati, 2016). Didukung hasil penelitian Puspitasari (2011) bahwa terdapat pengaruh yang signifikan dari kepuasan pelanggan terhadap niat beli ulang pada pelanggan. Berdasarkan hasil penelitian tersebut dapat dikemukakan hipotesis sebagai berikut:

\section{H4: Customer Satisfaction berpengaruh positif terhadap minat beli ulang}

Word Of Mouth merupakan jalur yang paling kuat bagi bisnis untuk mendapatkan pelanggan baru. Dalam penelitian ini terdapat temuan yang keempat yaitu adanya pengaruh signifikan positif kepuasan pelanggan terhadap Word Of Mouth. Penemuan tersebut juga ditemukan pada penelitian yang menyatakan bahwa adanya pengaruh positif hubungan antara kepuasan pelanggan terhadap word of mouth. Penemuan tersebut membuktikan pendapat yang mengatakan bahwa kepuasan pelanggan akan memperkuat terjadinya Word Of Mouth.

\section{H5: Customer Satisfaction berpengaruh positif terhadap Word Of Mouth}




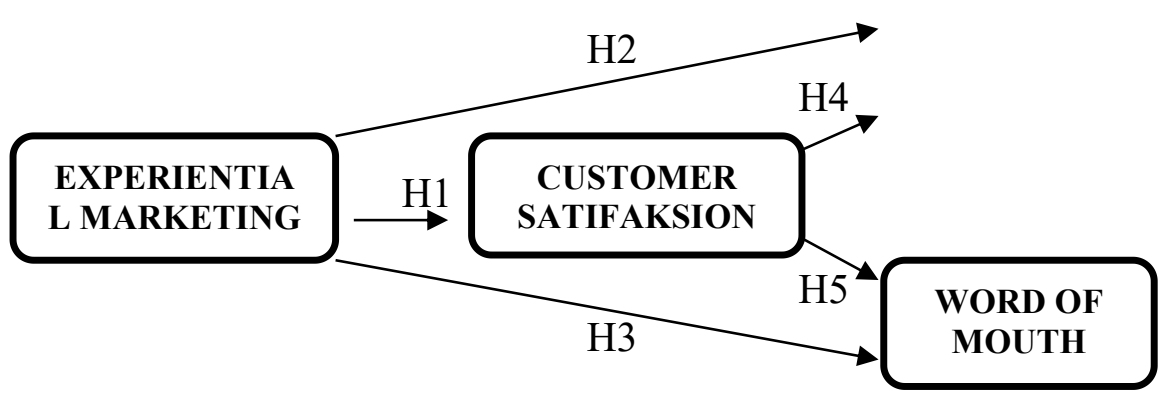

Gambar 1 Kerangka Penelitian

\section{METODE PENELITIAN}

\section{Rancangan atau Desain penelitian}

Jenis penelitian yang digunakan dalam penelitian ini adalah kuantitatif dengan menggunakan kuesioner. Populasi dalam penelitian ini yaitu yang pernah berbelanja atau nongkrong di Legend Coffe Yogyakarta minimal sebanyak dua kali, secara teknis penulis tidak dapat meneliti semua pelanggan Legend Coffee maka dilakukan terhadap sebagian dari populasi yang disebut sampel. Dalam penelitian ini jumlah sampel sebanyak 100 responden. Dimana cara penarikan sampel dilakukan dengan menggunakan teknik random sampling. Teknik random sampling merupakan teknik pengambilan sampel dari anggota populasi yang dilakukan secara acak tanpa memperhatikan strata yang ada dalam populasi itu.

\section{Sumber Data}

Dalam penelitian ini data yang di gunakan merupakan data primer yang dimana sumber data tersebut adalah langsung memberikan data kepada pengumpulan data, serta teknik pengumpulan data menggunakan kuesioner dan diberikan kepada pelanggan Legend Coffee Yogyakarta. Kuesioner dalam penelitian ini berisi tentang daftar pertanyaan yang memuat karakteristik responden serta pertanyaan pertanyaan dari beberapa indikator variabel bebas maupun terikat seperti, usia, status,pekerjaan dan penghasilan. Pertanyaan dalam kuesioner harus sesuai dengan indikator indikator yang berhubungan dengan variabel penelitian.pengukuran variabel bebas dan variabel terikat dalam kuesioner adalah menggunakan skala likert dan skala penilaian (skor) 1 sampai 5,dengan variasi jawaban untuk masing masing item pertanyaan adalah " Sangat Setuju (5)", "Setuju (4)", " Netral (3)", "Tidak Setuju (2)", dan " Sangat Tidak Setuju (1)".

\section{Pengembangan Instrument Penelitian}

Instrumen penelitian adalah alat atau fasilitas yang digunakan oleh peneliti dalam mengumpulkan data agar pekerjaannya lebih mudah dan hasilnya baik, dalam artian lebih cermat, lengkap dan sistematis sehingga mudah untuk diolah. Secara operasional variabel pada penelitian ini terdiri dari variabel bebas dan variabel terikat. Berdasarkan hipotesis yang telah dipaparkan, maka indikator pada penelitian ini adalah sebagai berikut:

\section{Tabel 1 Indikator Penelitian}

\begin{tabular}{|c|c|c|c|}
\hline $\mathrm{NO}$ & Variabel & Definisi & Indikator \\
\hline 1. & $\begin{array}{c}\text { Experiential } \\
\text { Marketing } \\
\text { (X) }\end{array}$ & $\begin{array}{l}\text { Experiential marketing yaitu konsep } \\
\text { pemasaran yang bertujuan untuk } \\
\text { membentuk pelanggan yang loyal dengan } \\
\text { cara menyentuh emosi pelanggan dengan } \\
\text { menciptakan pengalaman-pengalaman } \\
\text { positif dan suatu perasaan yang positif } \\
\text { terhadap jasa dan produk mereka. }\end{array}$ & $\begin{array}{ll}\text { 1. } & \text { Sense } \\
\text { 2. } & \text { Feel. } \\
\text { 3. } & \text { Think. } \\
\text { 4. } & \text { Act } \\
\text { 5. } & \text { Relate }\end{array}$ \\
\hline 2. & Customer & Kotler \& Keller (2009:177) kepuasaan & Harga \\
\hline
\end{tabular}




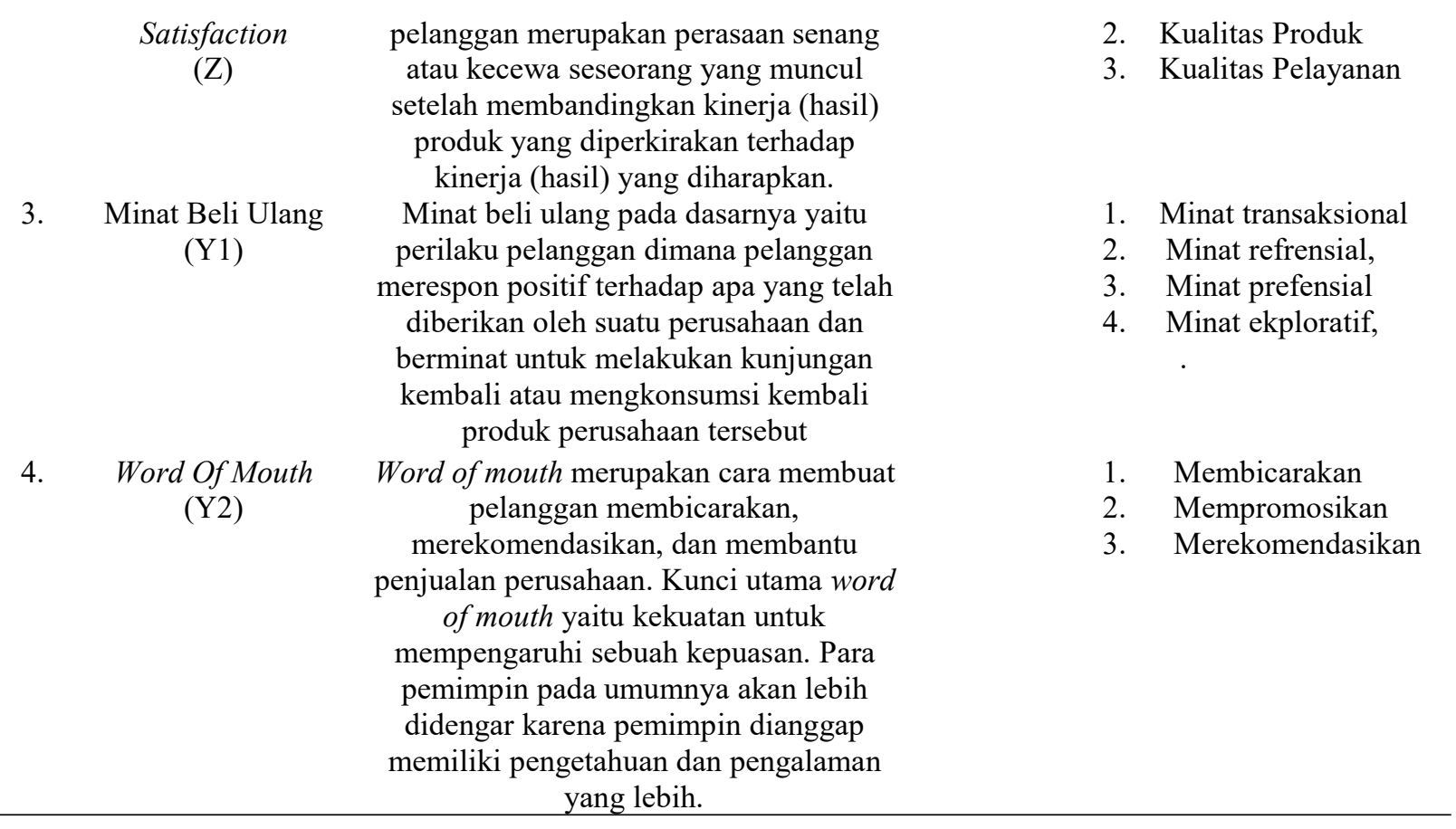

\section{HASIL DAN PEMBAHASAN}

Berdasarkan hasil penelitian, dapat dideskripsikan karakteristik responden berdasarkan usia pelanggan Legend Coffee Yogyakarta yaitu sebagai berikut:

Tabel 2 Usia

\begin{tabular}{ccc}
\hline Kategori & Frekuensi & Prosentase \\
\hline 15-20 Tahun & 12 & 12.0 \\
21-25 Tahun & 59 & 59.0 \\
26-30 Tahun & 22 & 22.0 \\
> 30 Tahun & 7 & 7.0 \\
Total & 100 & 100.0 \\
\hline
\end{tabular}

Berdasarkan tabel 2 dapat disimpulkan bahwa mayoritas responden dalam penelitian ini berusia 21 sampai dengan 25 tahun yakni sebanyak 59 orang.

Berdasarkan hasil penelitian, dapat dideskripsikan karakteristik responden berdasarkan status pernikahan pelanggan Legend Coffee Yogyakarta yaitu sebagai berikut:

Tabel 3 Status

\begin{tabular}{ccc}
\hline Kategori & Frekuensi & Prosentase \\
& & \\
\hline Menikah & 41 & 41.0 \\
Belum Menikah & 55 & 55.0 \\
Lainnya & 4 & 4.0 \\
Total & 100 & 100.0 \\
\hline
\end{tabular}

Berdasarkan table 3 dapat disimpulkan bahwa sebsebagian besar adalah responden termasuk dalam kategori belum menikah yaitu sebanyak 55 responden $(55,0 \%)$.

Berdasarkan hasil penelitian, dapat dideskripsikan karakteristik responden berdasarkan jenis pekerjaan pelanggan Legend Coffee Yogyakarta yaitu sebagai berikut: 


\begin{tabular}{ccc}
\hline Kategori & Frekuensi & Prosentase \\
\hline Pegawai Negeri & 17 & 17.0 \\
Wiraswasta & 23 & 23.0 \\
Karyawan Swasta & 34 & 34.0 \\
Lainnya & 26 & 26.0 \\
Total & 100 & 100.0 \\
\hline
\end{tabular}

Berdasarkan tabel 4 dapat disimpulkan bahwa sebagian besar adalah responden termasuk dalam kategori karyawan swasta yaitu sebanyak 34 responden $(34,0 \%)$.

\section{Tingkat Pendapatan Pelanggan Legend Coffee Yogyakarta}

Berdasarkan hasil penelitian, dapat dideskripsikan karakteristik responden berdasarkan tingkat pendapatan pelanggan Legend Coffee Yogyakarta yaitu sebagai berikut:

Tabel 5 Pendapatan

\begin{tabular}{ccc}
\hline Kategori & Frekuensi & Prosentase \\
\hline < Rp. 2.000.000 & 11 & 11.0 \\
Rp. 2.000.000 - Rp. 3.000.000 & 39 & 39.0 \\
Rp. 3.000.001 - Rp. 4.000.000 & 26 & 26.0 \\
Rp. 4.000.001 - Rp. 5.000.000 & 20 & 20.0 \\
> Rp. 5.000.000 & 4 & 4.0 \\
Total & 100 & 100.0 \\
\hline Sumber : Lampiran 3 & &
\end{tabular}

Berdasarkan tabel 5 dapat diketahui bahwa karakteristik responden berdasarkan tingkat pendapatan pelanggan Legend Coffee Yogyakarta, sebagian besar adalah responden termasuk dalam kategori Rp. 2.000.000 - Rp. 3.000 .000 yaitu sebanyak 39 responden (39,0\%).

\section{Uji Validitas}

Hal yang dilakukan sebelum menunjukkan bahwa semua indikator pernyataan layak dijadikan instrumen penelitian adalah melakukan uji sampel besar sebanyak 100 responden. Tingkat signifikansi 5\% jika probabilitas $<0,05$ maka pernyataan tersebut valid. Sedangkan jika nilai probabilitas $\geq 0,05$ maka pernyataan tersebut tidak valid.

\begin{tabular}{ccccc}
\multicolumn{2}{c}{ Tabel 6 Hasil Uji Validitas dari Item - Item Variabel Penelitian } \\
\hline Variabel & Item Pertanyaan & r hitung & r tabel & Keterangan \\
\hline & X1.1 & 0.860 & 0,195 & Valid \\
& X1.2 & 0.885 & 0,195 & Valid \\
X1.3 & 0.847 & 0,195 & Valid \\
X1.4 & 0.850 & 0,195 & Valid \\
Experiential & X1.5 & 0.871 & 0,195 & Valid \\
Marketing & X1.6 & 0.838 & 0,195 & Valid \\
& X1.7 & 0.847 & 0,195 & Valid \\
& X1.8 & 0.854 & 0,195 & Valid \\
& X1.9 & 0.864 & 0,195 & Valid \\
& X1.10 & 0.861 & 0,195 & Valid \\
& X1.11 & 0.847 & 0,195 & Valid \\
X1.12 & 0.862 & 0,195 & Valid \\
Customer & X1.13 & 0.875 & 0,195 & Valid \\
Satisfaction & Z.1 & 0.857 & 0,195 & Valid \\
& Z.2 & 0.880 & 0,195 & Valid \\
& Z.3 & 0.850 & 0,195 & Valid \\
& Z.5 & 0.872 & 0,195 & Valid \\
Minat Beli & Z.6 & 0.868 & 0,195 & Valid \\
Ulang & Y1.1 & 0.838 & 0,195 & Valid \\
& Y1.2 & 0.842 & 0,195 & Valid \\
& Y1.3 & 0.884 & 0,195 & Valid \\
& Y1.4 & 0.803 & 0,195 & Valid \\
& & 0.817 & 0,195 & Valid
\end{tabular}




\begin{tabular}{ccccc} 
& Y1.5 & 0.810 & 0,195 & Valid \\
& Y1.6 & 0.853 & 0,195 & Valid \\
& Y1.7 & 0.814 & 0,195 & Valid \\
Y1.8 & 0.846 & 0,195 & Valid \\
Word Of & Y2.1 & 0.843 & 0,195 & Valid \\
Mouth & Y2.3 & 0.914 & 0,195 & Valid \\
& Y2.4 & 0.877 & 0,195 & Valid \\
& Y2.5 & 0.905 & 0,195 & Valid \\
& Y2.6 & 0.924 & 0,195 & Valid \\
\hline
\end{tabular}

Berdasarkan hasil uji validitas dengan jumlah 100 responden dapat diketahui bahwa seluruh pernyataan mengenai Experiential Marketing, Customer Satisfaction, Minat Beli Ulang dan Word Of Mouth yang diajukan untuk responden pelanggan Legend Coffee Yogyakarta adalah valid karena dilihat dari nilai $r$ hitung $>r$ tabel, sehingga dapat disimpulkan bahwa seluruh pernyataan yang ada dalam kuesioner tersebut dapat dikatakan layak sebagai instrumen untuk mengukur data penelitian.

\section{Uji Reliabilitas}

Hal yang dilakukan setelah menunjukkan bahwa semua variabel pernyataan layak dijadikan instrumen penelitian yaitu melakukan uji sampel besar sebanyak 100 responden Pernyataan dapat di katakan reliabel jika nilai Cronbach's Alpha $>0,6$. Berikut ini adalah hasil uji reliabel:

\begin{tabular}{ccc} 
Tabel 7 Hasil Uji Reliabilitas dari Item - Item Variabel Penelitian & Cronbach's Alpha & Keterangan \\
\hline Variabel & 0.970 & Reliabel \\
Experiential Marketing & 0.930 & Reliabel \\
Customer Satisfaction & 0.937 & Reliabel \\
Minat Beli Ulang & 0.947 & Reliabel \\
Word Of Mouth & &
\end{tabular}

Berdasarkan tabel 7 hasil uji reliabilitas dari 100 responden dapat diketahui bahwa nilai Cronbach's Alpha dari variabel Experiential Marketing sebesar 0,970, Customer Satisfaction sebesar 0,930, Minat Beli Ulang sebesar 0,937, dan Word Of Mouth sebesar 0,947, sehingga dapat disimpulkan bahwa semua variabel dalam pernyataan dinyatakan reliabel karena telah memenuhi nilai yang disyaratkan yaitu dengan nilai Cronbach Alpha $>0,6$.

\section{Uji Asumsi Klasik}

Uji Normalitas

Uji ini adalah untuk menguji apakah pengamatan berdistribusi secara normal atau tidak, uji ini mengunakan kolmogorov smirnov. Hasil uji Normalitas dapat dilihat pada tabel dibawah ini

Tabel 8. Uji Normalitas Persamaan 1

Unstandardized Residual

Asymp. Sig. (2-tailed)

Tabel 9 Uji Normalitas Persamaan 2

\begin{tabular}{lr}
\hline & Unstandardized Residual \\
Asymp. Sig. (2-tailed) & .474 \\
\hline
\end{tabular}

Tabel 10 Uji Normalitas Persamaan 3 
Berdasarkan tabel 8, 9, 10 dapat diketahui experiential marketing terhadap customer satisfaction nilai asymp.sig sebesar 0,749>0,05 sehingga dapat disimpulkan bahwa data berdistribusi normal. Selanjutnya pada tabel 4.12 experiential marketing dan customer satisfaction terhadap minat beli ulang dapat diketahui nilai asymp. sig sebesar 0,474>0,05 sehingga dapat disimpulkan bahwa data berdistribusi normal. Serta pada tabel 4.13 experiential marketing dan customer satisfaction terhadap word of mouth dapat diketahui nilai asymp.sig sebesar 0,102>0,05 sehingga dapat disimpulkan bahwa data berdistribusi normal.

\section{Uji Heteroskedastisitas}

Suatu asumsi penting dari model regresi linier klasik adalah bahwa gangguan (disturbance) yang muncul dalam regresi adalah homoskedastisitas, yaitu semua gangguan tadi mempunyai varian yang sama. Hasil uji Heteroskedastisitas dapat dilihat pada tabel berikut :

Tabel 11 Uji Glejser Heteroskedastisitas Persamaan 1

\begin{tabular}{|c|c|c|c|}
\hline Variabel & Sig & Batas & Keterangan \\
\hline Experiential Markwting & 0,617 & $>0,05$ & Tidak terjadi heterokedasitas \\
\hline \multicolumn{4}{|c|}{ Tabel 12 Uji Glejser Heteroskedastisitas Persamaan 2} \\
\hline Variabel & Sig & Batas & Keterangan \\
\hline Experiental Marketing & 0,202 & $>0,05$ & Tidak terjadi heterokedasitas \\
\hline Costumer Satisfaction & 0,141 & $>0,05$ & Tidak terjadi heterokedasitas \\
\hline
\end{tabular}

Tabel 13 Uji Glejser Heteroskedastisitas Persamaan 3

\begin{tabular}{l|c|c|c}
\hline \multicolumn{1}{c|}{ Variabel } & Sig & Batas & Keterangan \\
\hline Experiental Marketing & 0,520 & $>0,05$ & Tidak terjadi heterokedasitas \\
Costumer Satisfaction & 0,221 & $>0,05$ & Tidak terjadi heterokedasitas \\
\hline
\end{tabular}

Berdasarkan tabel diatas dapat diketahui bahwa uji glejser heteroskedastisitas dinyatakan nilai signifikan variabel independen diatas lebih besar dari 0,05. Maka dapat disimpulkan bahwa tidak terjadi heteroskedastisitas dalam model ini.

\section{Uji Multikolineritas}

Uji multikolineritas bertujuan untuk mengetahui apakah dalam model regresi ditemukan adanya korelasi antar variabel bebas. Model regresi yang baik seharusnya tidak terjadi korelasi antar variabel bebas. Untuk mengetahui ada atau tidaknya multikolineritas maka dapat dilihat dari nilai Varians Inflation Factor (VIF) dan tolerance $(\alpha)$.

Tabel 14 Uji Multikolineartias Persamaan 1

\begin{tabular}{cccc}
\hline Variabel & Tolerance & VIF & Keterangan \\
\hline Experiential Marketing & 1.000 & 1.000 & Tidak terjadi multikolinieritas \\
\hline & & & \\
& Tabel 15 Uji Multikolineartias Persamaan 2 \\
\hline Variabel & Tolerance & VIF & Keterangan \\
\hline Experiential Marketing & 0.748 & 1.336 & Tidak terjadi multikolinieritas \\
Customer Satisfaction & 0.748 & 1.336 & Tidak terjadi multikolinieritas \\
\hline
\end{tabular}


Tabel 16 Uji Multikolineartias Persamaan 3

\begin{tabular}{cccc}
\hline Variabel & Tolerance & VIF & Keterangan \\
\hline Experiential Marketing & 0.748 & 1.336 & Tidak terjadi multikolinieritas \\
Customer Satisfaction & 0.748 & 1.336 & Tidak terjadi multikolinieritas \\
\hline
\end{tabular}

Berdasarkan tabel diatas dapat diketahui bahwa nilai tolerance value $>0,10$ atau nilai $\mathrm{VIF}<$ 10 maka tidak terjadi multikolinieritas.

\section{Analisis Regresi}

Dalam model analisis regresi akan dilakukan analisis uji t (lampiran 3) dan akan menunjukkan koefisien $(\beta)$ untuk masing-masing variable. Dapat diketahui nilai dari koefisien konstanta adalah 8,824 koefisien ekperiential marketing 0,502, sehingga diperoleh persamaan $\mathrm{CS}=8,824+0,502 \mathrm{EM}+\mathrm{e}$. Nilai dari koefisien konstanta adalah 9,150 koefisien ekperiential marketing 0,261 koefisien customer satisfaction 0,556, sehingga diperoleh persamaan sebagai berikut MBU $=9,150+261+556+$ e. Koefisien konstanta 9,805 dengan experiential marketing 0,189 koefisien customer satisfaction 0,475 sehingga diperoleh persamaan WOM= $9,805+0,189+0,475+\mathrm{e}$.

\section{Uji Hipotesis}

Uji Signifikan Individu (Uji Statistik t)

Uji statistik (uji t) dimaksudkan untuk menunjukkan seberapa jauh pengaruh satu variabel independen secara individual menerangkan variasi variabel dependen. Diketahui rumus $\mathrm{t}$ - tabel yaitu $\mathrm{t}$ tabel $(\mathrm{df}=100-2, \mathrm{df}=98)$ sehingga diketahui $\mathrm{t}$ - tabel adalah 1,66055

Tabel 17 Hasil Analisis Uji t

Coefficients $^{\text {a }}$

\begin{tabular}{|c|c|c|c|c|c|c|}
\hline \multirow{2}{*}{\multicolumn{2}{|c|}{ Model }} & \multicolumn{2}{|c|}{$\begin{array}{l}\text { Unstandardized } \\
\text { Coefficients }\end{array}$} & $\begin{array}{l}\text { Standardized } \\
\text { Coefficients }\end{array}$ & \multirow[t]{2}{*}{$\mathrm{t}$} & \multirow[t]{2}{*}{ Sig. } \\
\hline & & $\mathrm{B}$ & Std. Error & Beta & & \\
\hline \multirow{2}{*}{1} & (Constant) & 8.824 & 1.790 & & 4.931 & .000 \\
\hline & Experiental Marketing & .225 & .039 & .502 & 5.740 & .000 \\
\hline
\end{tabular}

a. Dependent Variable: Costumer Satisfaction

Tabel 18 Hasil Analisis Uji t

Coefficients $^{\mathrm{a}}$

\begin{tabular}{|l|l|r|r|r|r|r|}
\hline \multirow{2}{*}{ Model } & \multicolumn{2}{|c|}{$\begin{array}{c}\text { Unstandardized } \\
\text { Coefficients }\end{array}$} & \multicolumn{2}{c|}{$\begin{array}{c}\text { Standardized } \\
\text { Coefficients }\end{array}$} & \multirow{2}{*}{$\mathrm{t}$} & \multirow{2}{*}{ Sig. } \\
\cline { 3 - 7 } \multicolumn{2}{|c|}{} & \multicolumn{1}{c|}{ B } & Std. Error & Beta & & \\
\hline \multirow{3}{*}{1} & 9.150 & 2.274 & & 4.024 & .000 \\
\cline { 2 - 7 } & Experiental Marketing & .166 & .051 & .261 & 3.214 & .002 \\
\cline { 2 - 7 } & Costumer Satisfaction & .788 & .115 & .556 & 6.856 & .000 \\
\hline
\end{tabular}

a. Dependent Variable: Minat Beli Ulang

Tabel 19 Hasil Analisis Uji t

Coefficients $^{\mathbf{a}}$

\begin{tabular}{|c|c|c|c|c|c|c|}
\hline \multirow{2}{*}{\multicolumn{2}{|c|}{ Model }} & \multicolumn{2}{|c|}{$\begin{array}{l}\text { Unstandardized } \\
\text { Coefficients }\end{array}$} & \multirow{2}{*}{$\begin{array}{c}\text { Standardized } \\
\text { Coefficients }\end{array}$} & \multirow[t]{2}{*}{$\mathrm{t}$} & \multirow[t]{2}{*}{ Sig. } \\
\hline & & $\mathrm{B}$ & Std. Error & & & \\
\hline \multirow{3}{*}{1} & (Constant) & 9.805 & 2.269 & & 4.321 & .000 \\
\hline & Experiental Marketing & .103 & .051 & .189 & 2.000 & .048 \\
\hline & Costumer Satisfaction & .576 & .115 & .475 & 5.019 & .000 \\
\hline
\end{tabular}

a. Dependent Variable: Word Of Mouth 
Hasil uji t nilai sig. Dapat disimpulkan sebagai berikut :

i Berdasarkan tabel 17 di atas dapat diketahui hasil pengujian signifikansi menunjukkan bahwa terdapat nilai probabilitas sebesar $0.000(0,000 \leq 0,05)$. Nilai tersebut dapat membuktikan $\mathrm{Ha}_{1}$ diterima, yang berarti bahwa "Experiential Marketing berpengaruh positif terhadap Customer Satisfaction".

ii Berdasarkan tabel 18 di atas dapat diketahui hasil pengujian signifikansi menunjukkan bahwa terdapat nilai probabilitas sebesar $0.002(0,002 \leq 0,05)$. Nilai tersebut dapat membuktikan $\mathrm{Ha}_{2}$ diterima, yang berarti bahwa "Experiential Marketing berpengaruh positif terhadap Minat Beli Ulang".

iii Berdasarkan tabel 19 di atas dapat diketahui hasil pengujian signifikansi menunjukkan bahwa terdapat nilai probabilitas sebesar $0.048(0,048 \leq 0,05)$. Nilai tersebut dapat membuktikan $\mathrm{Ha}_{3}$ diterima, yang berarti bahwa "Experiential Marketing berpengaruh positif terhadap Word Of Mouth".

iv Berdasarkan tabel $18 \mathrm{di}$ atas dapat diketahui hasil pengujian signifikansi menunjukkan bahwa terdapat nilai probabilitas sebesar $0,000(0,000 \leq 0,05)$. Nilai tersebut dapat membuktikan $\mathrm{Ha}_{4}$ diterima, yang berarti bahwa "Costumer Satisfaction berpengaruh positif terhadap Minat Beli Ulang”.

v Berdasarkan tabel 19 di atas dapat diketahui hasil pengujian signifikansi menunjukkan bahwa terdapat nilai probabilitas sebesar $0,000(0,000 \leq 0,05)$. Nilai tersebut dapat membuktikan $\mathrm{Ha}_{5}$ diterima, yang berarti bahwa Coutomer Satisfaction berpengaruh positif terhadap Word Of Mouth

\section{Uji Sobel / Sobel Test}

Pengujian peran mediasi variabel intervening dari variabel dependen terhadap variabel independen dilakukan dengan perhitungan rumus Sobel:

\section{Pengaruh Experiential Marketing Terhadap Minat Beli Ulang Melalui Customer Satisfaction}

a. Koefisien antara variabel independen Experiential Marketing dan variabel intervening Customer Satisfaction

\section{Keterangan:}

a : koefisien regresi variabel independen terhadap variabel mediasi

b : koefisien regresi variabel mediasi terhadap variabel dependen.

Sea : standard error of estimation dari pengaruh variabel independen terhadap variabel mediasi.

$\mathrm{SEb}$ : standard error of estimation dari pengaruh variabel mediasi terhadap variabel dependen.

$$
\begin{array}{ll}
\mathrm{a} & =0,502 \\
\mathrm{~b} & =0,556 \\
\mathrm{~S} e_{a} & =0,039 \\
S e_{b} & =0,115
\end{array}
$$

Tabel 20

Koefisien Experiential Marketing terhadap Customer Satisfaction

\begin{tabular}{lcc}
\hline Model & Std. Error & Beta \\
\hline Experiential Marketing & .039 & .502 \\
\hline a. Dependent Variabel : Customer Satisfaction & & \\
\hline
\end{tabular}

a. Dependent Variabel : Customer Satisfaction

b. Koefisien antara variabel independen Minat Beli Ulang dan variabel intervening Customer Satisfaction 


\section{Tabel 21 Koefisien Customer Satisfaction terhadap Minat Beli Ulang}

\begin{tabular}{lccc}
\hline Model & Std. Error & Beta & \\
\hline Customer Satisfaction & .115 & .556
\end{tabular}

a. Dependent Variabel : Minat Beli Ulang

Hasil analisis dengan Sobel Test Calculator For The Significant of Mediation Jris Preacher :
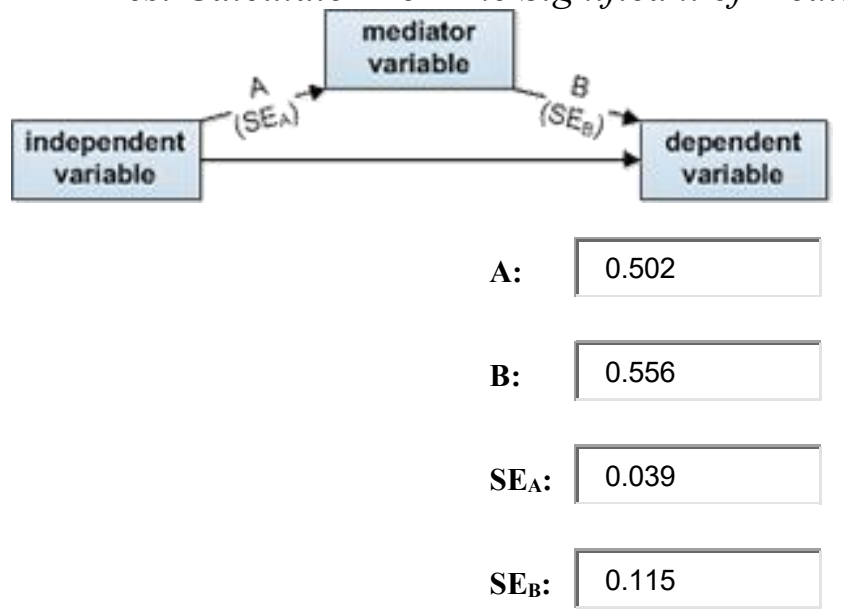

Calculate!

Sobel test statistic: $\quad \mathbf{4 . 5 2 6 0 3 8 7 9}$

One-tailed probability: 0.0000030

Two-tailed probability:0.00000601

Dari hasil perhitungan sobel test diatas mendapatkan nilai z sebesar 4.526, karena nilai $\mathrm{z}$ yang diperoleh sebesar 4.526>1.96 dengan tingkat signifikan $5 \%$ maka membuktikan bahwa Customer Satisfaction full memediasi hubungan pengaruh Experiential Marketing terhadap Minat Beli Ulang.

\section{Pengaruh Experiential Marketing Terhadap Word of Mouth Melalui Customer} Satisfaction

a. Pengaruh Experiential Marketing Terhadap Word Of Mouth Melalui Customer Koefisien antara variabel independen Experiential Marketing dan variabel intervening Customer Satisfaction

Keterangan:

a : koefisien regresi variabel independen terhadap variabel mediasi

b : koefisien regresi variabel mediasi terhadap variabel dependen.

Sea :standard error of estimation dari pengaruh variabel independen terhadap variabel mediasi.

Seb :standard error of estimation dari pengaruh variabel mediasi terhadap variabel dependen.

a $=0,502$

$\mathrm{b}=0,475$

$S e_{a}=0,039$

$S e_{b}=0,115$

Tabel 22 Koefisien Experiential Marketing terhadap CustomeSatisfaction 


\begin{tabular}{lcc}
\hline Model & Std. Error & Beta \\
\hline Experiential Marketing & .039 & .502
\end{tabular}

a. Dependent Variabel : Customer Satisfaction

b. Koefisien antara variabel independen Minat Beli Ulang dan variabel intervening Customer Satisfaction

Tabel 23 Koefisien Customer Satisfaction terhadap Word Of Mouth

\begin{tabular}{lccc}
\hline Model & Std. Error & Beta & \\
\hline Customer Satisfaction & .115 & .475
\end{tabular}

a. Dependent Variabel: Word Of Mouth

Hasil analisis dengan Sobel Test Calculator For The Significant of Mediation Jris Preacher :

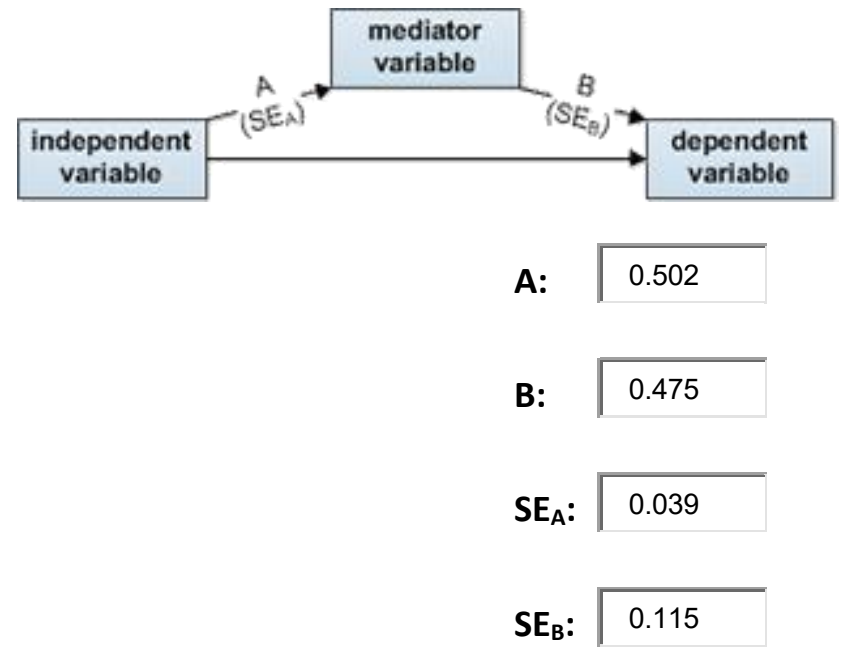

Calculate!

\begin{abstract}
Sobel test statistic: $\quad 3.93290809$
One-tailed probability: 0.00004196

Two-tailed probability: 0.00008392
\end{abstract}

Dari hasil perhitungan sobel test di atas mendapatkan nilai $\mathrm{z}$ sebesar 3.932, karena nilai $\mathrm{z}$ yang diperoleh sebesar $3.932>1.96$ dengan tingkat signifikan 5\% maka membuktikan bahwa Customer Satisfaction full memediasi hubungan pengaruh Experiential Marketing terhadap Word Of Mouth

\title{
PENUTUP
}

Berdasarkan hasil penelitian yang telah dilakukan mengenai Pengaruh Experiential Marketing terhadap Minat Beli Ulang dan Word Of Mouth dengan Customer Satisfaction sebagai variabel intervening dapat disimpulkan Variabel Experiential Marketing berpengaruh positif terhadap Costumer Satisfaction pelanggan Legend Coffee Yogyakarta berdasarkan uji t dengan nilai signifikansi $0,000<0,05$. Hasil penelitian menunjukan hipotesis pertama diterima. Variabel Experiential Marketing berpengaruh positif terhadap Minat Beli Ulang pelanggan Legend Coffee Yogyakarta berdasarkan hasil iji t dengan nilai signifikansi 0,002 < 0,05. Hasil penelitian menunjukan hipotesis kedua diterima. Experiential Marketing berpengaruh positif terhadap Word Of Mouth pelanggan Legend Coffee Yogyakarta berdasarkan hasil uji t dengan nilai signifikansi $0,048<0,05$. Hasil penelitian menunjukan 
hipotesis ketiga diterima. Costumer Satisfaction berpengaruh positif terhadap Minat Beli Ulang pelanggan Legend Coffee Yogyakarta berdasarkan hasil uji t dengan nilai signifikansi $0,000<0,05$. Hasil penelitian menunjukan hipotesis keempat diterima. Costumer Satisfaction berpengaruh positif terhadap Word Of Mouth pelanggan Legend Coffee Yogyakarta berdasarkan hasil uji t dengan nilai signifikansi $0,000<0,05$. Hasil menunjukan hipotesis kelima diterima.

Berdasarkan kesimpulan diatas, maka saran yang dapat diberikan sebagai bahan masukan yaitu Experiential Marketing terhadap Costumer Satisfaction berpengaruh positif dan signifikan. Dalam indikator Experiential Marketing mean yang paling rendah yaitu saya merasa sofa atau kursi di Legend Coffee memiliki ukuran yang sesuai dengan keinginan. Maka dari itu perusahaan harus memperhatikan fasilitas seperti sofa supaya pelanggan merasa puas. Experiential Marketing terhadap Minat Beli Ulang berpengaruh positif dan signifikan. Pada variabel Experiential Marketing mean paling rendah yaitu saya merasa sofa atau kursi di Legend Coffee memiliki ukuran yang sesuai dengan keinginan. Maka dari itu perusahaan harus memperhatikan fasilitas seperti sofa supaya meningkatkan minat beli ulang. Experiential Marketing terhadap Word Of Mouth berpengaruh positif dan signifikan. Pada variabel Experiential Marketing mean paling rendah yaitu saya merasa sofa atau kursi di Legend Coffee memiliki ukuran yang sesuai dengan keinginan. Maka dari itu perusahaan harus memperhatikan fasilitas seperti sofa supaya meningkatkan Word Of Mouth. Costumer Satisfaction terhadap Minat Beli Ulang berpengaruh positif dan signifikan. Pada variabel Costumer Satisfaction mean paling rendah yaitu saya merasa hidangan makanan dan minuman di Legend Coffee bersih. Maka dari itu perusahaan harus memperhatikan tata hidangan supaya kelihatan lebih bersih supaya meningkatkan minat beli ulang. Costumer Satisfaction terhadap Word Of Mouth berpengaruh positif dan signifikan. Pada variabel Costumer Satisfaction mean paling rendah yaitu saya merasa hidangan makanan dan minuman di Legend Coffee bersih. Maka dari itu perusahaan harus memperhatikan tata hidangan supaya kelihatan lebih bersih supaya meningkatkan Word Of Mouth. Diharapkan dengan adanya penelitian ini menjadi referensi peneliti selanjutnya. Penelitian berikutnya dapat menggunakan variabel bebas diluar penelitian ini namun dengan objek yang sama. Ataupun dapat menggunakan variabel sama, namun lebih memperluas wilayah penelitian ataupun menambahkan sampel yang digunakan sehingga akan memberikan pandangan yang lebih luas. Selain itu peneliti yang akan datang dapat mengembangkan variabel intervening selain Customer Satisfaction.

\section{DAFTAR PUSTAKA}

Allameh, S. M., Pool, J. K., Jaberi, A., Salehzadeh, R., \& Asadi, H. (2015). Factors influencing sport tourists' revisit intentions. Asia Pacific Journal of Marketing and Logistics.

Barimbing, C. A. A., \& Sari, D. (2015). Pengaruh Experiential Marketing Terhadap Kepuasan Pelanggan (Studi Pada Pelanggan Mujigae Resto Ciwalk Bandung). eProceedings of Management, 2(1).

Dewi, R. K., Kumadji, S., \& Mawardi, M. K. (2015). Pengaruh Experiential Marketing terhadap Kepuasan Pelanggan dan Dampaknya pada Loyalitas Pelanggan (Survei Pada Pelanggan Tempat Wisata Jawa Timur Park 1 Kota Wisata Batu). Jurnal Administrasi Bisnis, 28(1), 1-6.

Kotler, P. dan Keller, K. L. (2009). Manajemen pemasaran (13th ed.) jilid 1. Jakarta: Erlangga. Mismiwati, M. M. (2016). Pengaruh Kepuasan Pelanggan, Kualitas Produk, Dan Experiential Marketing Terhadap Word Of Mouth Pada Percetakan Sabilul Haq. I-Economics: A Research Journal On Islamic Economics, 2(1), 19-30. 
Palma, M. A., \& Andjarwati, A. L. (2016). Pengaruh Kualitas Produk, Kemudahan, dan Harga terhadap Niat Beli Ulang dengan Kepuasan sebagai Variabel Intervening (Studi pada Pelanggan Produk Fashion melalui Toko Online di Surabaya). Jurnal Riset Ekonomi dan Manajemen, 16(1), 84-104.

Puspitasari, N. (2011). Sejarah dan Perkembangan Asuransi Islam serta Perbedaannya dengan Asuransi Konvensional. Jurnal Ekonomi Akuntansi dan Manajemen, 10(2), 35-47. 